\title{
Effects on Consumer Behavior Due to Post Purchase Regret Associated with Online Shopping
}

\author{
K.Rajagopal, Vaishali Mahajan, Pankaj Sharma, Akshay Udas
}

\begin{abstract}
Anonymization is a device of hiding the information to any such degree, that an unlawful customer couldn't get whatever from the information, of direction an analyzer will get vital data[4].The term records privacy is associated with data accumulating and allotment of information. Safety issues rise in exceptional sector, as an instance, human administrations, financial institution place, web based totally definitely existence data,and so forth.It's miles one of the difficult troubles while sharing or disseminating the data among one to numerous hotspots for research cause and records evaluation[2].Many affiliations moreover launch huge scaled down scale data. It bars an person's brief identity marks like call, cope with and contain specific facts like intercourse, $D O B$, marital repute, Pin-code, which can be united with other open information to see a person[3]. This derivation ambush may be endeavored you purchased any sensitive facts from informal community put together, with the useful resource of that putting the security of a person in risk. To save you such ambushes through way of converting littler scale facts, k-anonymization is used. In this paper, we provide a computational advent technique to releasing records from a personal desk with the last intention that the identity of any character to whom the released information mean can't be virtually recognized[1]. It's far based upon the difficulty of hypothesis, from which set away developments may be superseded with dependable but much much less unequivocal alternatives, and of ok-loss of clarity.
\end{abstract}

Rundown phrases - facts conveying, coverage defensive, adequate-anonymization, accumulating.

\section{INTRODUCTION}

With significant increase in promotion of the e-commerce platforms, consumers now prefer shopping for products online. The advances in technology and digitalization of these e-commerce platforms have brought a revolution in the spectrum of online shopping by enhancing the consumer's shopping experience and further providing them with the privilege of shopping from the comfort of their homes. The customers overwhelming response has resulted in explosive rises in sales. Considering all the major benefits

Revised Manuscript Received on September 10, 2019.

K.Rajagopal, Marketing department, Symbiosis Centre for (Deemed), Pune, Maharashtra, India.

(Email: k_rajagopal@scmhrd.edu)

Vaishali Mahajan, Marketing department, Symbiosis Centre for Management and Human Resource Development, Symbiosis International (Deemed), Pune, Maharashtra, India.

(Email: vaishali_mahajan@scmhrd.edu)

Pankaj Sharma, Finance department, Symbiosis Centre for Management and Human Resource Development, Symbiosis International (Deemed), Pune, Maharashtra, India.

(Email: pankaj_sharma@scmhrd.edu)

Akshay Udas, Marketing department, Symbiosis Centre for Management and Human Resource Development, Symbiosis International (Deemed), Pune, Maharashtra, India.

(Email: akshay_udas@scmhrd.edu) Management and Human Resource Development, Symbiosis International

of online shopping, one might still agree with the fact that the probability of the disliking the product after arrival increases since the customer cannot see and touch the product before buying. Disliking the product after it has arrived provokes disparity and regret in the consumer causing post purchase regret. The research aims to study the effects of consumer behavior due to post purchase regret associated with online shopping. The paper also is an attempt to find the imperial relations between consumer behavior and post purchase regret associated with online shopping. The author seeks to discover the mediating facts that the consumer demonstrates post the regret. It is an attempt to find the major behavioral aspects that are affected the most and as to how they can be addressed by $\mathrm{e}$ commerce portals.

The study wishes to approach the post choice evaluation and examining the role of disappointment and regret on consumer behaviour. It is an attempt to find the different influences on consumer behaviour due to post purchase regret and how regret affects the future prospects of buying a product. It is a study on how the psychological traits of a consumer affect behaviour after experiencing regret. The purpose is to find the behavioural traits exhibited by the consumer in the later stages of the purchase cycle. From a psychological perspective we explore the emotional outcomes of the regret. Also to discover the consumer's behaviour exhibited to minimise or eliminate remorse and to come in terms with the experienced regret. We try to predict how changes in sentiments trigger the recovery efforts of post-purchase behaviour.

The major factor which contributed to the surge in sales in the e commerce is the consumer's preference in purchasing products online thereby saving time and effort. To add to these factors, the technological advancements have elevated the shopping experience. The swell in response from the consumers is a valid proof that they are well adapted to the advancements in technology from the selection process to the payment techniques. The e commerce portals also have customized their platforms for potential customers with user friendly interfaces, simplified access and fast logistics. They try to meet the consumer's needs by offering multiple choices of merchandise for the desired product. The shoppers are exposed to an ocean of products which differ in quality and price. The attractive discounts, alluring offers on buying combinations of products and schemes associated with the desired products, the "free" gifts or vouchers,

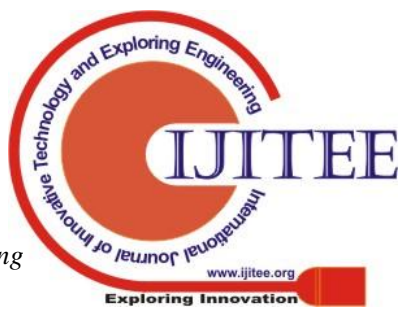


cash back offers all give the e-commerce platform an upper hand over the retail business. These attractive offers, discounts and schemes tend to allure the consumer in buying a product which is unnecessary.

Though the online shopping portals have an upper hand on the traditional brick and mortar stores, the major disadvantage still prevails that the consumers that shop online cannot touch and feel the product that they are buying. This adds to the probability of the consumer disliking the product after it has arrived. Also one cannot deny the probability that the consumer may dislike the arrived product. This also may be due to the fact the product might not meet the expectation of consumer in terms of quality or quantity. As an optimum solution to these problems, online shopping portals provide customers with reliable replacement policies and often refund cash in case of dissatisfaction. The study is thus an attempt to find the behavioural aspects that are exhibited by consumers after experiencing post purchase regret. The study examines the characteristic personality components associated with post purchase regret. It also explores the outcome of the post purchase regret from a consumer's point of view.

\section{LITERATURE REVIEW}

Regret is an emotion that humans tend to avoid, restrain and are motivated to avoid, suppress and contradict to experience Regret is the pessimistic emotion encountered when people realize that their current situation would have been better if they had decided or acted differently. A human being faces regret when he/she compares the current situation with a what-if situation, or when thinking about the alternatives which were left unexplored or ignored. When consumers perceive that their purchasing decisions were wrong, they feel regret (Landman, 1987; \& Mittal, 2000; Heitmann, Lehmann, and Herrmann, 2007) [1],[2],[3]. The feeling of regret can be determined or measured Tsiros in terms of intensity from a consumer's perspective. The intensity of regret may be proportional to the time elapsed since the decision. Post purchase regret can be classified under the short termed regret, since it induces regret about a certain action rather than inaction. This in turn makes people more psychologically aware about the decision and may affect their decision with the purchase portal/ product in the future.

Post-purchase regret is an unfavorable term for to marketers whose consumers purchased their brands and products and regret about them. The consumer behaviour literature shows that post- purchase regret is accompanied by low-consumer satisfaction (Inman, Dyer, and Jia, 1997; Taylor \&Scheider, 1998; Tsiros\& Mittal, 2000)[4],[5],[2]. Low satisfaction leads to no repurchase intention (Tsiros\& Mittal, 2000),[2], a tendency to shift to alternative brands (Zeelenberg\&Pieters, 1999; Bui, 2011; Garcia \& Perez, 2011), [6],[7],[8] and negative word-of-mouth about the brand (Garcia \& Perez, 2011) [8]. Therefore, knowing the antecedents that lead to consumers' regret, after making a purchase, is important to marketers. Consumers who experience regret would not engage in any behaviour, but they would also share their feelings of regret or negative opinions with the existing or potential consumers. This, in return, would create a negative image of the enterprise (Karafakıoglu, 2006:107)[9].

The e-commerce must try to address these issues since the shopping experience associated with them is different than the retail market. Return and cash refund policies may not be enough for consumers to deal with post purchase regret since the sentiment attached to it intensifies in terms of psychological suffering. This suffering may result into loss of customer to competition. The e- commerce must pay minute attention to consumer's loyalty in order to reduce the post purchase regret.

Through this study I have tried to pursue the sentiment of consumer behaviour affected due to post purchase regret associated with online shopping in a multidimensional aspect. I have tried to analyze the consumer behaviour in terms of the following aspects and this is a sincere attempt to study the effects of consumer behaviour due to post purchase regret. The aspects of consumer behaviour considered are as follows:

\section{Personal Characteristics -}

Age, gender and marital status of the respondents are considered to evaluate the sample on the basis of demography. These characteristics were considered since consumer behaviour fairly depends on the demography of consumers. They play an important role in purchase decision as well.

Characteristic behaviour of refraining from visiting an e commerce website again due to experienced post purchase regret - Post purchase regret experienced on a specific e commerce portal or site may cause the customer to refrain from visiting the site again in the near future. This exhibited behaviour is further evaluated in the research. I thereby wish to investigate the reasons why a customer refrains from visiting a site again. This characteristic of a customer plays the most important part with respect to consumer behaviour with respect to post purchase regret since the e commerce portal losses the customer forever and thereby potential sales. The aspects or reasons that a customer refrains from visiting the site considered in the study are experienced regret, return policies of the e commerce portal, finding that a product is sold at a lower price on some other portal. The "pricing of the product' is considered since this factor may cause the customers to feel cheated and thereby refrain from visiting the site.

The other aspects of consumer behaviour considered for investigation are - amount of money spent on the purchase - The study investigates that larger the amount of money spent on a purchase, larger would be the consideration before buying the product and hence lesser will be the regret or vice versa.

Another aspect of consumer behaviour considered in the study is - what the customer does with the product 
because of return policies and its effect from a gender based perspective. This refers to investigate whether gender is a significant factor in deciding what a respondent does with the product in case of no return policy. It also involves the effect of customer service of e commerce portals on the experienced regret.

Going through literature review, it is found that certain underlying gaps that were left undiscovered gaps and would like to test the follows hypothesis-

\section{Hol -}

There is no significant co relation between experienced post purchase regret and the respondents refraining from visiting an e commerce site.

$\mathrm{Hal}$ -

There is significant co relation between experienced post purchase regret and the respondents refraining from visiting an e commerce site.

\section{$\mathrm{Ho} 2-$}

There is no significant influence of return policies of an online portal refraining from visiting the site.

\section{$\mathrm{Ha} 2-$}

There is significant influence of return policies of an online portal refraining from visiting the site.

\section{Ho3 -}

There is no significant influence of 'finding that a product is sold at a lower price on some other portal' on refraining from visiting the site.

\section{$\mathrm{Ha3}-$}

There is significant influence of 'finding that a product is sold at a lower price on some other portal' on refraining from visiting the site.

\section{Ho4 -}

There is no significant impact of amount of money spent on the purchase that is regretted later on the experienced regret.

\section{$\mathrm{Ha} 4$ -}

There is significant impact of amount of money spent on the purchase that is regretted later on the experienced regret.

\section{RESEARCH METHODOLOGY}

\section{A. Research Problem}

The aim is to provide an insight on which are the peculiar behavioral traits exhibited by the how and why the consumers tend to encounter the regret. Further, it also explores the various reasons due to which the consumers regretted buying a product online. The study focuses on the occasions and frequency of regret experienced. The behavioral aspects considered for this study are the major behavioral traits articulated by consumers to express regret, the reactions to post purchase regret, the measures taken to eliminate or minimize regret and the resultant expressions to conceal regret associated from purchasing the product.
The objectives of the study are to

i. Determine aspects of consumer behaviour refraining from visiting the site again due to post purchase regret associated with online shopping.

ii. To investigate how the consumer, react to post purchase regrets and measures the intensity of regret.

iii. To find an insight on whether personal characteristics and demographics of a consumer affects consumer behaviour with respect to post purchase regret.

iv. To investigate whether the customers refrain from purchasing certain categories of products online due to avoid post purchase regret.

\section{Research Design}

The choice of topic arises from experienced post purchase regret and observing the affected consumer behaviour. This descriptive research intends to investigate the consumer behaviour affected due to post purchase regret in online shopping. The research is an attempt that can be used in the near future to derive to a solution that addresses the issue and minimise or eliminate negative consumer behaviour towards online shopping.

\section{Population of the Study and sample design}

This study targeted family members, friends and professional collegues, all with at least a bachelors' degree. They were selected as a sample because of their exposure to various online shopping portals. The questionnaire was prepared using Google forms. The sampling technique used was convenience sampling.

\section{E. Data Collection}

The fact is more than one method employed in the development of measures will result in greater confidence in findings". Webb et al.(1966) cited by (Bryman \& Bell, Business Research Method, 2011) ; Hence we used both qualitative and quantitative approach to collect the data for a brief study. Qualitative data is subjective whereas quantitative collection of data through numerical (Bryman \& Bell, 2010).Qualitative data collection help to understand consumer behaviour on the other hand quantitative approach help to measure consumer behaviour. A combination of these two methods is called "Triangulation". The data collected is segregated into two parts - Primary and Secondary data. For the study and analysis of the same survey questionnaires was designed on commercial website (Google forms). The questionnaire was filled by 40 people who are well acquainted with the online shopping portals. The secondary data was collected from relevant research papers, the information that was available on the internet and other online sources.

\section{B. Research Objectives}




\section{F. Methodology of data analysis}

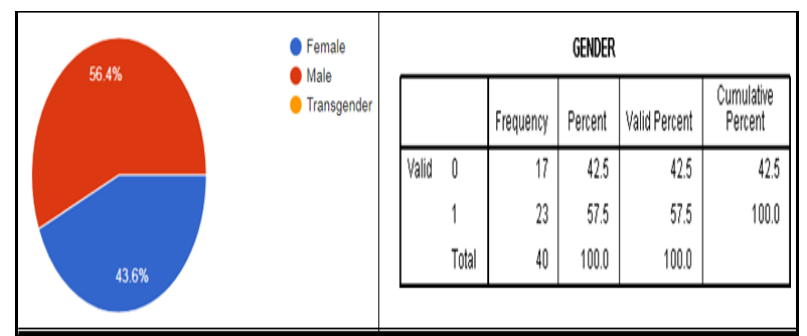

The data was analysed using software SPSS Version 19 and $\mathrm{R}$ studio version 3.4.3.

- $\quad$ Pearson's co relation was used to find if there is significant co relation between two variables.

- $\quad$ One sample $\mathrm{T}$ test, paired sample $\mathrm{T}$ test was used to test hypothesis.

- Chi square test was used to test and

- Logistic regression was used to make model along with factors in $\mathrm{R}$.

- Linear regression was used to find the dependent variables.

\section{DATA ANALYSIS,DISCUSSIONS AND RESULTS}

Age -

The first question was about the respondent's age. The age was divided into groups of below 18 years, between $18-24$ years , $25-34$ years , 35- 44 years , 45 - 54 years and 54 years and above. $77.5 \%$ respondents were between 25 to 34 years. $15 \%$ were in the age group $18-24$ years. $2.5 \%$ of the respondents were between 35 to 44 years. 2 respondents were in the age group of 45 to 54 years.

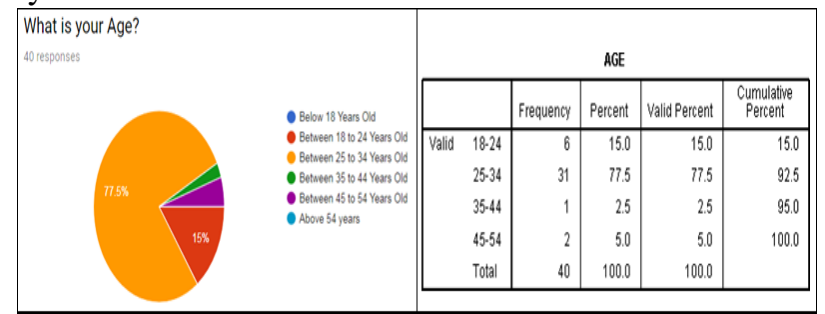

Gender-

The question was about the respondent's gender - 56.4 $\%$ were males and $43.6 \%$ of the respondents were females. 17 respondents were males and 23 respondents were females.

\section{Marital status -}

$55 \%$ respondents were married and $45 \%$ respondents stated their status as single.22 respondents were single and 18 were married

\section{The three factors -}

age, gender and marital status are considered to be important personal characteristics of the sample population. The detailed cross tabulation of the three characteristics is as follows-

Age and Gendervalidate the goodness of fit.

Out of the 40 respondents, 06 females were between the age group of 18- 24 years. 10 females and 21 males were between the age group of $25-34$ years. 01 male respondent was between the age group of 35 - 44years. 01 females and 01 males were between the age group of $45-54$ years.

\section{Age and Marital status -}

06 respondents were single in the age group of $18-24$ years. In the age group of $25-34$ years -16 respondents were single and 15 were married. There were 1 married respondent in the age group of $35-44$ year. 2 married respondents belong to the age group of $45-54$ years.

\begin{tabular}{|} 
AGE * MARITAL_STATUS Crosstabulation \\
Count \\
\hline \multirow{3}{*}{} & & \multicolumn{2}{|c|}{ MARITAL_STATUS } & \multirow{2}{*}{ Total } \\
\cline { 3 - 5 } & 0 & 1 & 6 \\
\hline AGE & $18-24$ & 6 & 0 & 31 \\
& $25-34$ & 16 & 15 & 1 \\
& $35-44$ & 0 & 1 & 2 \\
& $45-54$ & 0 & 2 & 40 \\
\hline
\end{tabular}

Marital status and gender-

08 female respondents 14 males were single. 09 females and 09 male respondents were married. The question was intended to find what types of products respondents purchase online, to find frequently purchased products from online portals. $65 \%$ respondent's buy electronic goods such as laptop, TV and mobiles. 90\% respondents brought Clothing and apparels. 24 respondents purchase footwear. $22.5 \%$ respondents purchase food and grocery items online and $12.5 \%$ respondents purchased house hold furniture and decor. The other respondents brought jewelry and cosmetics.

\begin{tabular}{|c|c|c|c|c|}
\hline \multicolumn{5}{|c|}{$\begin{array}{l}\text { GENDER * MARITAL_STATUS Crosstabulation } \\
\text { Count }\end{array}$} \\
\hline & & \multicolumn{2}{|c|}{ MARITAL_STATUS } & \multirow[b]{2}{*}{ Total } \\
\hline & & 0 & 1 & \\
\hline \multirow[t]{2}{*}{ GENDER } & 0 & 8 & 9 & 17 \\
\hline & 1 & 14 & 9 & 23 \\
\hline Total & & 22 & 18 & 40 \\
\hline
\end{tabular}

- $\quad$ Post Purchase regret due to online shopping:

The researcher intended to find whether the respondent has experienced regret due to online shopping. $72.5 \%$ respondents have experienced regret and $28 \%$ have never experienced the same while shopping online.

- $\quad$ Regret due to finding that the product was sold at a lower price:

The research made an in-depth probing on to gain an insight on whether the respondents keep a tab of the 
changing prices and does it affect the regret behaviour. Through this, I attempted to measure the amount of rumination that the consumer experiences due to regret. $40 \%$ respondents claim to sometimes experience regret due to the reason, $35 \%$ rarely face the issue and $13 \%$ respondents experience regret because of finding that the product was sold at a lower price.

- $\quad$ Refrain from visiting the site due to regret of purchase:

The response on the subject revealed that the consumers refrain from visiting a site if they experience regret due to their purchase.

$20 \%$ respondents stated that they always tend to refrain from visiting a site if and when they experience regret. $25 \%$ claimed to often do the same. $20 \%$ sometimes refrain, $20 \%$ rarely and $15 \%$ continue to visit the site.

- Monetary loss occurred due to purchasing a product that the respondents regretted later:

Probing was done to find if there is a co - relation between amounts of money spent and post purchase regret.17.5 \% have spent less than 500 rupees.40\% respondents stated that the money they spent on the purchase was between 500-1000 rupees. $35 \%$ claimed to have spent between 1000- 5000 rupees and $7.5 \%$ have spent more than 5000 rupees on a purchase that they regretted later.

- Frequency of regret due to a portal's return policies:

Consumers often face regret because of the return policies. The researcher investigated to find whether 'return policies' are reasons for refraining from visiting the site again. $20.5 \%$ respondents often face issues with online return policies. $33.3 \%$ respondents sometimes have regretted their purchase because of the return policies, $35 \%$ have rarely faced the issue and $7.7 \%$ have never regretted shopping due to an online portal's return policy.

- $\quad$ Ceased to purchase a specific product category due to regret-

While attempting to find whether respondents exhibit regret in terms of refraining from buying certain categories of products, it was evident that $27 \%$ respondents ceased to buy electronic goods, 30\% respondents' ceased to buy clothing from online portals due to regret. $13.5 \%$ refrained from buying food and groceries. $19 \%$ stated that they refrained from buying furniture and decor.

- In case of a no return policy which behaviors do consumers exhibit -

To find consumer's reaction to regret was the intention.

$38 \%$ respondents gift the product to someone else, $36 \%$ respondents continue using the product to conceal sadness and $26 \%$ respondents don't use the product at all.

- Post purchase regret and consumer's way of expressing the same:

This question was asked to find consumer's reaction to regret

Majority of the respondents tell their family and friends about the experience and write reviews about the product on the portal. $10 \%$ respondents post the issue on social media and $12 \%$ respondents do nothing about it.

When it was attempted to find a solution to the regret and strategize for a positive consumer behaviour post the regret.

$55 \%$ respondents strongly agree that good customer service and refunds reduce regret. $38 \%$ agree to the same and $8 \%$ are neutral towards the same.

\section{Data analysis -}

Testing each of the hypothesis stated in the Literature review, thereby deriving conclusions -

\section{Hypothesis}

Hol -

There is no significant co relation between experienced post purchase regret and the respondents refraining from visiting an e commerce site.

Hal -

There is significant co relation between experienced post purchase regret and the respondents refraining from visiting an e commerce site.

\section{Method used-}

Pearson's correlation and one sample T test

Results -

Conclusion -

\begin{tabular}{|l|l|}
\hline Test & Test Value \\
\hline $\begin{array}{l}\text { Pearson's } \\
\text { correlation }\end{array}$ & $r=0.5653386$ \\
\hline One sample T test & $p$-value $=3.766 \times 10^{\wedge}-14$ \\
\hline
\end{tabular}

1. The value of Pearson's correlation $=0.5653386$. According to rule of thumb $\mathrm{r}=0.5653386<0.6$ signifies a moderately strong co relation, as experiences of regret increases, respondent's probability of refraining from visiting the site increases.

2. The $\mathrm{p}$ value of one sample $\mathrm{T}$ test $<0.05$, hence rejecting the null hypothesis and accepting alternate hypothesis - There is significant co relation between experienced post purchase regret and the respondents refraining from visiting an e commerce site

\section{Hypothesis -}

Ho2 -

There is no significant influence of return policies of an online portal refraining from visiting the site.

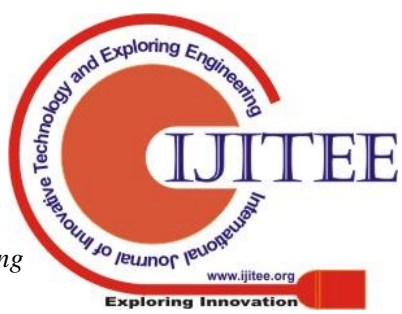




\section{$\mathrm{Ha} 2-$}

There is significant influence of return policies of an online portal refraining from visiting the site.

Method used -

One sample $\mathrm{T}$ test

Results-

\begin{tabular}{|l|l|}
\hline Test & Test Value \\
\hline One sample T test & p-value $=0.3196$ \\
\hline
\end{tabular}

Conclusion -

The $\mathrm{p}$ value of one sample $\mathrm{T}$ test $>0.05$, hence accepting the null hypothesis and rejecting alternate hypothesis -There is no significant influence of return policies of an online portal refraining from visiting the site.

\section{Hypothesis -}

Ho3 -

There is no significant influence of 'finding that a product is sold at a lower price on some other portal' on refraining from visiting the site.

Ha3 -

There is significant influence of 'finding that a product is sold at a lower price on some other portal' on refraining from visiting the site.

Method used-

One sample T test

Results -

\begin{tabular}{|l|l|}
\hline Test & Test Value \\
\hline One sample T test & p-value $=0.01125$ \\
\hline
\end{tabular}

Conclusion -

The $\mathrm{p}$ value of one sample $\mathrm{T}$ test $<0.05$, hence rejecting the null hypothesis and accepting alternate hypothesis - There is significant influence of 'finding that a product is sold at a lower price on some other portal' on refraining from visiting the site.

\section{Hypothesis -}

Ho4 -

There is no significant impact of amount of money spent on the purchase that is regretted later on the experienced post purchase regret.

\section{Ha4 -}

There is significant impact of amount of money spent on the purchase that is regretted later on the experienced post purchase regret

\section{Method used -}

Pearson's co relation, One sample T test

$$
\text { Results - }
$$

\begin{tabular}{|l|l|}
\hline Test & Test Value \\
\hline $\begin{array}{l}\text { Pearson's } \\
\text { correlation }\end{array}$ & $\mathbf{0 . 1 6 9 9 8 2 5}$ \\
\hline One sample T test & p-value $=5.213 \times 1^{\wedge}{ }^{\wedge}-$ \\
\hline
\end{tabular}

Conclusion -

1.

The value of Pearson's correlation $=$ 0.5653386. According to rule of thumb $\mathrm{r}=$ $0.5653386<0.6$ signifies a very weak co relation. Concluding that the more is the amount of money involved in a purchase, more is the consideration of the product being purchased and hence less is the regret experienced.

2.

The $\mathrm{p}$ value of one sample $\mathrm{T}$ test < 0.05 , hence rejecting the null hypothesis and accepting alternate hypothesis - There is significant impact of amount of money spent on the purchase that is regretted later on the experienced post purchase regret.

A logistic Regression model for experienced post purchase regret aimed at finding significant factors or aspects of consumer behaviour that are affected. The dependent factor is whether the respondent has experienced post purchase regret associated with online shopping or not. Since the variable has binomial values, logistic regression was used. The factors considered are respondent's age, gender, marital status, finding that the product was sold at a lower price on some other portal, amount of money spent on a purchase, the e commerce site's return policies and customer service.

The logistic regression equation -

$\mathrm{Y}=-1.1638(\mathrm{x} 1)-1.5481(\mathrm{x} 2)+0.7272(\mathrm{x} 3)+1.1907$ $(\mathrm{x} 4)+0.2227(\mathrm{x} 5)-0.7047(\mathrm{x} 6)-0.4438(\mathrm{x} 7)+4.7101$

$\mathrm{Y}$ - The post purchase regret experienced due to online shopping $\mathrm{x} 1$ - Age of the respondent

$\mathrm{x} 2$ - Gender of the respondent

$\mathrm{x} 3$ - Marital status of the respondent

$\mathrm{x} 4$ - Finding that the product was sold at a lower price on some other portal

x 5 - Amount of money spent on a purchase

$\mathrm{x} 6$ - return policies of the site

x7 - Customer service of the site

AIC of the model: 49.375

After the step wise regression, the most significant factor that affects the dependent variable is that with the least BIC of 47.104. i.e - Finding that the product was sold at a lower price on some other portal is the major factor that causes post purchase regret associated with online shopping. The consumer feels cheated and despaired because of the same.

Linear regression to find the significant factors due to which a consumer refrains from visiting a site due to post purchase. The dependent variable considered was refrain from visiting the site and the independent factors considered were return policies of a e commerce site and 
finding that the product purchased was sold at a lower price on some other site.

The linear regression equation is -

$\mathrm{Y}=0.08646(\mathrm{x} 1)+0.67785(\mathrm{x} 2)+1.05430$

$\mathrm{Y}-$ Refrain from site.

$\mathrm{x} 1$ - Return policies of a site

$\mathrm{x} 2$ - Finding that the product purchased was sold at a lower price on some other site

$\mathrm{AIC}=18.39$

Adjusted R-squared: 0.2138

After the step wise regression, the most significant factor that affects the dependent variable is that with the least AIC of 16.66 i.e. - Finding that the product was sold at a lower price on some other portal is the major factor that causes the consumer to refrain from visiting a specific site due to experienced regret.

\section{SUMMARY AND CONCLUSION}

The study was conducted utilizing data pertaining to both Primary and Secondary. The aim was to find the aspects of consumer behaviour that are affected because of post purchase regret associated with online shopping

- There is significant co relation between experienced post purchase regret and the respondents refraining from visiting an e commerce site. Post purchase regret directly influences a consumer behaviour expressed by refraining from visiting the site again.

- Return policies of an e commerce site do not influence the consumer's behaviour of refraining from visiting the site again.

- $\quad$ 'Finding that a product is sold at a lower price on some other portal' significantly influences the consumer's behaviour of refraining from visiting the site again.

- There is significant impact of amount of money spent on the purchase that is regretted later on the experienced regret. The factors co relates - larger the amount of money spent on a purchase, lesser is the probability of experiencing post purchase regret.

- $\quad$ Finding that the product was sold at a lower price on some other portal is the major factor that causes post purchase regret associated with online shopping. The consumer feels cheated and despaired because of the same.

- $\quad$ Finding that the product was sold at a lower price on some other portal is the major factor that causes the consumer to refrain from visiting a specific site due to experienced regret.

- There is no significant impact of gender on experienced post purchase regret associated with online shopping. (Chi square test, p-value $=0.07855$ )

- Majority of the respondents (consumers) express their post purchase regret by ranting it out to their family and friends and writing reviews about the product on the portal. Even if the number of respondents that post on social media about their negative experiences are less, considering the huge impact and reach of social media the damage to the site cannot be denied as a matter of fact social media is a platform that reaches out to a wide strata of the society.
- There is no significant difference of gender with what a respondent does with a product that he/she has regretted on what he/ she does with the product because of a 'no return' policy. (Chi square test, p-value $=0.006102)$. We can conclude through a pivot table, that majority of the males continue using the product and majority of female gift the product to someone else.

- There is significant influence of good customer service on experienced post purchase regret. ( $\mathrm{T}$ test, $\mathrm{p}$ value $=2.2 \times 10^{\wedge}-16$ )

\section{MANAGERIAL IMPLICATIONS}

$\bullet$

The study can help managers investigate the detailed effects of post purchase regret associated with online shopping on consumer behaviour.

The aspects of consumer behaviour considered in the study can be used in the near future to increase the addressability and acknowledgement of grievances and regret. Thereby reducing the intensity of experienced regret.

- The study provides an insight on the customer service from a regret perspective; the same can be used to develop a universal scale or process to evaluate reviews and feedback.

\section{FUTURE RESEARCH}

Through this study, the researchers have evaluated and investigated the major aspects of consumer behaviour that are affected due to post purchase regret associated with online shopping. Though the research attempts to cover major aspects, there still remains a research gap to investigate the other dimensions of regret.

- $\quad$ Future studies can also evaluate the other factors like brand switching intentions and the relation of these factors with the consumer's age, gender and other personal characteristics.

- $\quad$ The study can be extended with a seller's point of view. The addressability of the grievances and factors that have caused post purchase regret.

The researcher can also explore the changes in consumer behaviour due to post purchase regret on the consumer's future purchase decisions.

\section{LIMITATIONS}

- The major limitation is the inadequate sample population.

- $\quad$ There may be a possibility of generalized results since the sample was based on convenience.

- $\quad$ The population may vary in many socioeconomic conditions which might limit their resources, and affecting some other aspects or characteristics of consumer behaviour that were not considered in the study. 
- $\quad$ Pricing of a product and amount of money spent on a purchase that is regretted later is considered to be a reason of affecting consumer behaviour but the evaluation of these reasons from a consumer's point of view may be rational or from his/her perception and may not necessarily be aligned with others. The methods to evaluate the reason is not yet defined, hence this proves to be limitation.

- The psychological traits can be subjective and explaining certain aspects of consumer behaviour through a questionnaire is difficult and may often lead to confusion and uncertainty. Thus the research requires in depth qualitative research.

\section{MAJOR FINDINGS}

There is significant co relation between experienced post purchase regret and the respondents refraining from visiting an e-commerce site. Post purchase regret directly influences a consumer behaviour expressed by refraining from visiting the site again.

- Return policies of an e -commerce site do not influence the consumer's behaviour of refraining from visiting the site again.

- Finding that a product is sold at a lower price on some other portal' significantly influences the consumer's behaviour of refraining from visiting the site again

\section{REFERENCES}

1. Landman, J. (1987). Regret and elation following action and inaction: Affective responses to positive versus negative outcomes. Personality and Social Psychology Bulletin, 13(4), 524-536.

2. Tsiros, M., \& Mittal, V. (2000). Regret: A model of its antecedents and consequences in consumer decision making. Journal of Consumer Research, 26(4), 401-417.

3. Heitmann, M., Lehmann, D. R., \& Herrmann, A. (2007). Choice goal attainment and decision and consumption satisfaction. Journal of marketing research, 44(2), 234250.

4. Inman, J. J., Dyer, J. S., \& Jia, J. (1997). A generalized utility model of disappointment and regret effects on post-choice valuation. Marketing Science, 16(2), 97-111.

5. Saleh, M. A. H. (2012). An investigation of the relationship between unplanned buying and postpurchase regret. International Journal of Marketing Studies, 4(4), 106.

6. Zeelenberg, M., \& Pieters, R. (1999). Comparing service delivery to what might have been: Behavioral responses to regret and disappointment. Journal of Service Research, 2(1), 86-97.

7. Bui, A. L., Horwich, T. B., \& Fonarow, G. C. (2011). Epidemiology and risk profile of heart failure. Nature Reviews Cardiology, 8(1), 30.

8. Perez-Garcia, O., Escalante, F. M., de-Bashan, L. E., \& Bashan, Y. (2011). Heterotrophic cultures of microalgae: metabolism and potential products. Water research, 45(1), 11-36.

9. Yavuz, A. K. Ç. İ., \& KILINÇ, K. Tüketicilerin Alış Veriş Sonrası Pişmanlıklarının ve Gösterdikleri.

10. Landman, J. (1987). Regret: A theoretical and conceptual analysis.

11. Taylor, S. E., \& Schneider, S. K. (1989). Coping and the simulation of events. Social cognition, 7(2), 174-194.

12. Bui, M., Krishen, A. S., \& Bates, K. (2011). Modeling regret effects on consumer post-purchase decisions. European Journal of Marketing, 45(7/8), 10681090.

13. Bell, E., Bryman, A., \& Harley, B. (2018). Business research methods. Oxford university press.

14. Zeelenberg, M., \& Pieters, R. (1999). Comparing service delivery to what might have been: Behavioral responses to regret and disappointment. Journal of Service Research, 2(1), 86-97.

15. Sánchez-García, I., \& Currás-Pérez, R. (2011). Effects of dissatisfaction in tourist services: The role of anger and regret. Tourism Management, 32(6), 1397-1406.

16. Gilovich, T., \& Medvec, V. H. (1994). The temporal pattern to the experience of regret. Journal of personality and social psychology, 67(3), 357.

17. Sugden, R. (1985). Regret, recrimination and rationality. Theory and decision, 19(1), 77-99.

\section{AUTHORS PROFILE}

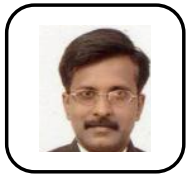

Kannan Rajagopal holds 15 years' experience of Teaching Management course both as Adjunct and Full Time Faculty in reputed Educational Institutions across the country. He has pursued his $\mathrm{PhD}$ in Marketing and $\mathrm{PhD}$ in HR and is associated currently with SCMHRD as a full time faculty, SIU Pune. He has presented research papers in reputed International Conferences in India and abroad. He has 2 decades of work experience in Automotive Marketing.

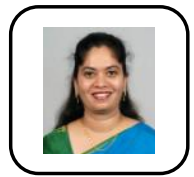

Vaishali Mahajan has 19 years of teaching Management subjects to the Masters(MBA) students. currently serves as Associate Professor and Head of the Department of Marketing Department at Symbiosis Centre for Management and Human Resource Development, Symbiosis International (Deemed), Pune. Her research interests' area includes service marketing, on line Marketing, and consumer Buying Behavior. She has presented several papers in the reputed International conferences.

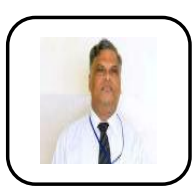

Pankaj Sharma has a rich professional experience of 16 years being extremely competent as a commercial manager in the Manufacturing Industry. He has an immense experience in academics as a Dean in reputed Business Schools in Pune. Currently he is the HOD of Finance at SCMHRD, SIU Pune. he has presented several international and national research papers in conferences. He has conducted MDPs for corporate and FDPs for faculty members.

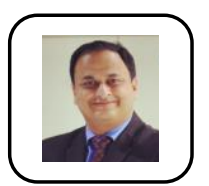

Akshay Udas skilled in data analytics as desire. Is experienced senior consultant with a demonstrated history of working on SAP solutions. His core interests lie in developing strategic IT solutions for business problems. He likes digging into complex data sets and producing insights that are data driven strategic recommendations. Currently pursuing his MBA in Marketing at SCMHRD, SIU Pune. His research interest area is consumer buying behavior specifically on-line buying behavior. 